The Journal of Society and Media, April 2021, Vol. 5(1) 42-57

https://journal.unesa.ac.id/index.php/jsm/index

E-ISSN 2580-1341 and P-ISSN 2721-0383

Accredited KEMENRISTEK/BRIN No.148/M/KPT/2020

DOI: 10.26740/jsm.v5n1.p42-57

\title{
Mediatization of Islam; The Case of The Indonesian Muslims In Hungary
}

\author{
Hazim Hazim $^{1 *}$, Nurul Musdholifah ${ }^{2}$ \\ ${ }^{1}$ Faculty of Social Science, Eotvos Lorand University, Budapest, Hungary \\ Email: hazimhaz@caesar.elte.hu \\ ${ }^{2}$ Faculty of Psychology and Education, University of Muhammadiyah Sidoarjo \\ Street Majapahit 666B Sidoarjo, East Java \\ Email:n.musdholifah@gmail.com
}

\begin{abstract}
This article addresses the mediatization of religion, mainly focusing on how Indonesian Muslims in Hungary mediatize their Islamic practices. It is a result of an empirical study incorporating two approaches, qualitative and quantitative methods. Participant observation and semi-structured in-depth interviews involving 18 informants were conducted to collect the quantitative data. In contrast, the quantitative data was generated from an online survey of 102 participants ( 60 males and 42 females). The result of the study shows that the lack of integration with local Islamic institutions affects the mediatization of Islam. The form of Islamic mediatization can be seen through their way of obtaining religious messages, news, and information which primarily relies on the Internet. Most of them depend on Social media, where YouTube channel was their favorite, followed by Facebook and Instagram, to obtain Islamic resources. The dependency upon media, particularly YouTube, has the potential to shift religious authority from institutional to personal power. While some scholars debate whether the mediatization of religion could encourage secularization, the case of Indonesian Muslims in the Hungarian context shows that instead of becoming more secular, the dependency upon media for religious practices affects them to be more religious.
\end{abstract}

Keywords: mediatization of religion, Indonesian Muslims, Hungary, social media, Islamic practices.

Paper type: Research paper

*Corresponding author: hazimhaz@caesar.elte.hu

Submitted: 2020-08-01; Accepted: 2021-04-04; Published: 2021-04-28

Cite this document: Hazim, Hazim, and Nurul Musdholifah. (2021). Mediatization of Islam; The Case of The Indonesian Muslims In Hungary. The Journal of Society and Media, 5(1), 42-57. DOI: 10.26740/jsm.v5n1.p42-57 


\section{INTRODUCTION}

This article addresses religion's mediatization, particularly attention to Indonesian Muslims living in Hungary. Investigating this issue is pivotal for some reasons. First, the population of Indonesian Muslims living in Hungary is small and does not have adequate Islamic infrastructure to fulfill their specific religious needs. Indonesian Islamic institutions in Hungary accommodating their religious interests are not available. It is difficult for this community to find Indonesian Muslim scholars who might help provide spiritual resources or information.

According to official data, the total number of Indonesians living in Hungary by 2021 is 416 people, comprised of workers, students, and those living in this country for family reunification (Embassy of the Republic of Indonesia in Budapest 2021). Among them, there is no reliable statistical data about the number of Indonesian Muslims in Hungary. They were expected to be around 50\% of the total population, meaning they would be about 200 people. This minority group lives in various cities, yet those who live in Budapest are predominant.

Second, as a minority group, Indonesian Muslims experience a severe problem of social integration into the local Muslim communities. Integration refers to the acculturation process of minority groups to a majority group where there is an interest in maintaining one's original culture and interacting with others (Berry and Sam 1997). By contrast, they tend to be "separation," meaning when a minority group members place a value on holding on to their original culture, at the same time, attempt to avoid interaction with the majority group (Berry and Sam 1997). Language is one of the primary hindrances limiting their integration since most of the local religious rituals, events, and ceremonies are carried out either in Arabic or Hungarian instead of in English, which not many Indonesians understand these languages.

Due to the facts, this article aims to investigate how the Indonesian Muslims in Hungary deal with the problems. More specifically, this study focuses on how they mediatize their religion rooted in the assumptions that they are actively using media for their religious needs, communicating spiritual messages, and managing media representation of their faith as a consequence of the poor integration with the local religious communities. 
Many scholars have widely used the concept of mediatization as a new theoretical approach to address the role and influence of media in societies in the digital age. There are two interrelated processes of social changes as characteristics of mediatization in an advanced society. The first concerns the evolution of media in the last decades from its previous function, working for another social institution to be more independent and autonomous social institutions. The second refers to the degree to which the media have been integrated into the working of other social institutions in which, through this integration, the media have partly been appropriated to serve the needs of these institutions (Hjarvard 2008, 2011; Lövheim 2014).

While some media theorists associate the term mediatization as the same as mediation (Lövheim 2014), Hjarvard (2011) argues that those terms have different meanings and consequences. According to him, mediation refers to the concrete acts of communication using a medium in a specific social context, the intervention of which can affect both the message and the relationship between sender and receiver. However, there will not necessarily have any substantial impacts of the use of a medium on other social institutions, including religious institutions. By contrast, Hjarvard describes mediatization as a more long-term process characterized by the change of social and cultural institutions as well as modes of social interaction as a consequence of the development of the media's effect (Hjarvard 2011; Lövheim 2014)

In the context of the mediatization of religion, it means that the media offers a great challenge to take over the role of religious institutions in conveying religious messages in public discourse. Furthermore, mediatization changes the "core elements" of religion, that is, how religion is given in a society (Hjarvard 2008, 2011; Lövheim 2014).

According to Hjarvard $(2008,2011)$, the mediatization of religion is characterized by the transformation of three aspects of religion. First, people's use as a primary source of religious information has changed from relying on religious institutions to the media. Second, as a consequence of the media becoming independent and autonomous institutions, the media have the authority to produce and distribute spiritual experiences. Media may provide a platform for the expression and circulation of individual beliefs. Popular media genres determine how media represent religious information and experiences, whereas existing 
religious symbols, practices, and beliefs become raw material for the media's agenda. Third, the new position in society, media have developed into social and cultural environments allowing media to take over many of the cultural and social functions of religious institutions, such as providing moral and spiritual guidance and a sense of community (Hjarvard 2008; Lövheim 2014).

Mediatization of religion itself implies various consequences depending on the particular religious and media contexts. While most scholars agree that the mediatization of religion affects an increasing plurality of representations of religion in the media landscape, they have different opinions on the individual level's implications. Some scholars believe that the mediatization of faith leads to increase individualization and secularization (Hepp 2009). In line with this view, Hjarvard (2008, 2011) argues there is a strong connection between the mediatization of religion and the secularization of society. His argument is grounded in his investigation of Western culture, particularly the Nordic Countries characterized by a low degree of institutional commitment and a high degree of individualized belief (Hjarvard 2008).

Yet, some scholars, particularly those viewing beyond the western context, do not believe the increase of individualization and secularization is a consequence of the mediatization of religion. Lynch (2011) is one of the scholars criticizing Hjarvard's theory of mediatization of religion and its implications. According to Lynch, the concept may only apply to particular religious, historical, social, and political contexts. More specifically, Lynch points out that Hjarvard's theory is most relevant to Northern and Western societies characterized by the prevalence of nonconfessional media institutions, decreasing direct public participation in religious institutions, the association of ecclesiastical authority with specific traditional institutions, and broader evidence of secularization. Lynch even argues that the mediatization of religion theory is helpful for grasping the complex relationships among media, religion, and social changes (Lynch 2011).

Setianto (2015), investigating Indonesian Muslim diasporas in the United States, has proven no correlation between the mediatization of religion and secularization. Indonesian Muslims in the US could carry out religious rituals without significant differences from their spiritual practices in actual society. Even they benefit from meditation on religion used as a way of internal "da'wah," 
particularly for promoting and sharing religious teaching among them. In addition, Setianto (2015) points out that mediatized Islam implies that Indonesian Muslims are more religious.

The presence of the Internet at the end of the $20^{\text {th }}$ century has become the mediatization of religion more massive in society. Some studies revealed that the new media, on the one hand, have encouraged people to become more active both in obtaining religious information and how interpreting religious messages (Ali 2010; Hutchings 2011; Setianto 2015). On the other hand, they have empowered individuals to perform self-representing their personal religious beliefs in digital media, potentially changing the conventional concept of religious authority (Lövheim and Lundmark 2019).

Concerning authority, it is a term initially conceptualized by Max Weber (1978) to explain a particular type of power in a society. He formulates three ideal authority types: traditional, charismatic, and legal-rational (Weber 1978). Yet, within the context of religious leaders, recent scholars have documented the changes of authority in a society affecting some aspects of religious institutions, such as hierarchy, structure, ideology, and text (Campbell 2007, 2012; Lövheim and Lundmark 2019). The central discussion on media and religious literature has revealed how religious authority shifts from institutional to individual-centered, for instance, webmasters, bloggers, and influencers (Hoover 2020; Lövheim and Lundmark 2019).

Considering the previous literature debate, this article focuses on the investigation of how mediatization of religion among Indonesian Muslim diasporas in Hungary and its implications. This is a challenging investigation since they have a robust religious-cultural background in their home country, Indonesia, but they live in a weak religious atmosphere, Hungary.

\section{METHODS}

This article results from an empirical study combining two methodological approaches, qualitative and quantitative. The qualitative method incorporated participant observation and semi-structured in-depth interviews. The statement was primarily focused on some mosques in Budapest, the capital city of Hungary; officially, there are five (5) mosques in Budapest, namely Alhuda, Darussalam, Türk Camisi Budapeşte (Turkish Mosque), Budapest mosque, and Hilmi Huszein 
mosque. The In-depth Interview involved 18 Indonesian Muslims, comprising ten males and eight females. The selected informants were determined through snowball sampling.

Complementing the qualitative data, an online survey circulated through google form was carried out involving 102 respondents (60 males and 42 females) who self-identified as Muslim and met the criteria of being 15 years or older and either living in Hungary for study, work, or family reunification for at least six months out of the year.

To analyze the qualitative data were analyzed using a Miles and Haberman data analysis approach comprising three steps; data reduction, data display, and conclusion drawing or verification. The results were compared and contrasted with the survey data to construct comprehensive findings.

\section{RESULTS AND DISCUSSION}

The need for integration into the local Islamic institutions. One of the most challenging things for Indonesian Muslims in Hungary is that they are not wellintegrated into local Islamic communities. On the contrary, they tend to be

"separated," meaning when the community members maintain their original culture at the same time attempt to avoid interaction with the local religious institutions (Berry and Sam 1997). Quantitatively, the paucity of integration into the local institutions can be seen, at least from the degree to which they participate in any Islamic practices, events, and ceremonies in the Hungarian mosques. The survey involved 102 respondents from 17 cities and predominated by students $(67,6 \%)$, while workers and family reunification were $22,5 \%$ and $9,8 \%$, respectively, showing a low degree of involvement. Only $7,8 \%$ of the respondents went to the mosques daily, $16,7 \%$ were weekly, and almost half of them stated that they went to the mosques once or twice a year or never went to the mosques anymore.

However, the lack of integration into the local religious communities for Indonesian Muslims does not mean that this is a consequence of the mediatization of religion leading them to be individualist and secular as conceptualized by mediatization of religion theorists such as Hjarvard (2008, 2011) and Hepp (2009). Indonesian Muslims in Hungary have different social contexts influencing their engagement with the local Muslim communities. Based on the in-depth interviews, 
the following reasons predominate their insufficient integration into Hungarian Muslim institutions; language barrier, time conflict, accessibility to the mosque, and the coronavirus pandemic.

Language is the main hindrance preventing them from having a close relationship with the local institutions. This is reasonable because most Indonesians living in Hungary rely on English, while none of the Islamic institutions officially uses English for Islamic rituals and ceremonies. For instance, in terms of Friday sermons, in Budapest, which has five mosques, three perform speeches in Arabic; one mosque uses Hungarian, while another is in Turkish. Some mosques also have weekly Islamic teachings. Hilmy Huzsein Mosque is an example of a mosque providing Islamic discussion guided by the Imam every Saturday. But the instruction is in Hungarian which is not understandable for most Indonesians.

Anggi, a Master student at Eotvost Lorand Univerity, (ELTE), pointed out:

"Jujur saja saya tidak banyak mendapatkan penambahan pengetahuan yang berarti selama mengikuti kegiatan keagamaan, setidaknya pada saat shalat Jumat. Alasannya adalah karena kendala bahasa. Saya selama ini mengikuti shalat jumat di masjid-masjid di Budapest yang menggunakan bahasa yang saya sendiri tidak faham karena khutbahnya menggunakan bahasa arab atau bahasa Turki. Mungkin akan sangat membantu bagi saya bila ada yang bahasa Inggris. Tetapi saya merasa mendapat manfaat ketika diskusi dengan sesama jamaah, karena kita dapat berkomunikasi dengan bahasa inggris. Kami bisa share sedikit pengetahuan keagamaan."

"To be honest, I didn't get much added to my knowledge while participating in religious events, at least during the Friday prayer ceremonies. The reason was because of the language barrier. I had participated in Friday prayers at mosques in Budapest, but I did not understand what they said because the sermons were in Arabic or Turkish. It would be helpful when the sermons were in English. But I got benefits when discussing with other fellows because we could communicate in English. We can share a little religious knowledge."

The survey also reported that more than $50 \%$ of the respondents stated that the religious teachings in the mosques do not contribute to sacred knowledge improvement. In contrast, less than $10 \%$ said the events were insightful for them. Most go to the most only to carry out their Friday prayer as an individual obligation, but they still need to get something more improving Islamic knowledge. As a result, 
Indonesian Muslims are not interested in actively engaging in the mosques' programs.

A time conflict between daily activities, either work or study, and their time for Islamic practices or events in the mosques is another reason. In Hungary, there is no given time for prayer. So, when the time for prayer comes, particularly Friday prayer, Muslims who work or study used to have a conflict of time. They must choose to continue their activities or leave them and then go to the mosques. Of course, some consequences might affect those who leave their actions to carry out a prayer.

Under this circumstance, some Muslims avoid the consequences and continue their daily activities. Otherwise, they go to the mosque when they are on holiday. As stated by Mira, a master's student at Eotvost Lorand Univerity (ELTE);

"Saya di sini merasakan tinggal di suasana yang sangat berbeda, kalau di Indonesia selain kita biasanya ada waktu-waktu khusus istirahat shalat, sehingga memungkinkan untuk ke masjid, atau setidaknya kita masih mudah menemukan musholah di tempat-tempat umum terdekat dari aktifitas kita, sementara di sini shalat harus benar-benar mengatur diri sendiri. Bahkan jujur saya sering telat waktu shalat karena menyesuaikan jam kuliah. Saya tidak berani meninggalkan kelas meskipun sudah waktu masuk shalat, karena tahu sendiri kan, taka ada peduli hak kita sebagai Muslim, sekalipun itu dosen-dosen kita. Jadi saya harus kompromi dengan keadaan ini”.

"Here I am feeling living in a very different atmosphere than when we were in Indonesia, besides we used to have special times for prayer breaks allowing us to go to the mosque, or at least we had no difficulties finding prayer rooms in any public places. Here we have to manage ourselves for the prayer times. I am often late for prayer because of the times conflict with my classes. I did not dare to leave the class even though it was time for prayer. You know, nobody cares about our rights as Muslims, even our lecturers. So I have to compromise with this situation."

Another cause why most of the respondents did not participate in the Islamic rituals when living in Hungary is the location of the mosques, which is far away from their living. As an illustration, some respondents stated that they had to go around 50-100 km or travel approximately 2-3 hours to reach a mosque. Some cities do not have mosques, such as in Veszprém, Komarom, Kaposvar, Tatabanya, Tata, and Szigethalom. The lack of Islamic infrastructure hinders Indonesian Muslims from being able to integrate into the local Muslim communities. 
The coronavirus pandemic in the last two years has become another challenge for Muslims to engage in local Islamic activities. Some mosques are closed during the outbreak, while others restrict their actions and change to online ceremonies. For instance, in Pecs, during the pandemic, the only mosque in this city, Pasha Qasim Mosque, has been closed since the COVID-19 pandemic occurred. There are no religious activities, even for Friday prayer. Consequently, those who need to go to the mosque must go to another city which is around $50 \mathrm{~km}$ far away. In Budapest, Hilmy Huzsein Mosque, located at Paskal street, had a weekly Islamic teaching program every Saturday morning. But during the COVID-19 outbreak, the program has been changed to be online. The change in the program affects the possibility of Indonesian Muslims participating in religious events.

Indonesian Muslim females experience more limitations in connecting with the local Muslim communities. For female Muslims, not many mosques have Islamic rituals or programs accommodating their existence in Hungary, as pointed out by Afriza, a Ph.D. student at Szeged University, who did not participate in the mosque anymore during living in Hungary because there were no special events for female Muslims.

The only community that allows Indonesian female Muslims to join is "Muslima in Budapest". This community is welcome for every female Muslim. This Islamic group had a weekly meeting in Budapest mosques, but during the coronavirus outbreak, the program was changed to be online during the coronavirus. However, only a few Indonesian females joined the group. Nurul Musdholifah, an active participant in the community, confirmed that a conflict of time between Indonesian females and the Muslima in the Budapest program might be the main reason why Indonesian Muslims are not involved in this community.

Due to the facts mentioned above, the Indonesian Muslims in Hungary have a problem with the integration process with the local Muslims, influenced by some reasons. While the language is the primary barrier, the absence of Islamic institutions in some cities and the conflict time prevent them from being able to integrate into the local communities. The coronavirus outbreak in the last two years has caused the acculturation process to become more complicated. These circumstances encourage Indonesian Muslims to find another way to deal with their religious issues. 
The Internet is the primary source of Islamic references. One of the characteristics of the mediatization of religion is that media has become a primary source of religious references (Hjarvard 2011). In Hungary, while there is a paucity of Hungarian Islamic institutions providing religious resources and a lack of integration with the local religious institutions, most Indonesian Muslims rely on the Internet to fulfill their spiritual needs. The Internet has become the favorite Islamic resource for this community. It means that the Internet plays an essential role in mediatizing Islam for Indonesian Muslims and takes over the function of Islamic institutions in providing religious resources.

In-depth interviews with some informants emphasize why Indonesian Muslims in Hungary prefer to use the Internet as the most favorite religious resource. Afriza best explains why Indonesian Muslims prefer to use the Internet as the primary resource of Islamic reference. According to her, understanding religious news and information through the Internet is the best way in the current situation where she is living, Szeged. In this city, there is no adequate mosque or Islamic institution, particularly for females allowing them to participate in religious rituals or events. In addition, the restrictive measures of the coronavirus outbreak in Hungary prevent the possibility of gathering among Muslims in Hungary.

Flexibility access is another consideration why most Indonesian Muslims in Hungary prefer to use the Internet to improve their religious knowledge. The Internet offers a lot of genres and topics to fulfill individuals' preferences. In general, thousands of Islamic scholars have each individual's characteristics, which are available on the Internet. By contrast, Hungarian Islamic institutions provide only one or two scholars.

Accessible anytime and anywhere is another charm of the Internet. As mentioned above, most Muslims have to manage their time between their daily activities and attending religious events. The Internet provides spiritual needs that are accessible without disrupting their activities. Muslims can obtain religious news or information while working, studying in universities, or staying at home. Anggi pointed out that he used to hear some holy speeches while working. He downloaded the Spotify application on his android to listen to any Islamic lecture, where Dr. Fahrudin Faiz is his favorite speaker concerning Islamic philosophy. 
These are the advantages of using the Internet, opening new ways of finding any religious news or information challenging the role of conventional religious institutions' authorities (Lövheim and Lundmark 2019). When some scholars (Ali 2010; Hutchings 2011; Setianto 2015) reveal that the easiness offered by the Internet has also encouraged people to be more active in obtaining religious messages, this also happens in Hungary. Most Indonesian Muslims are more intensive in accessing the Internet than going to mosques to get religious news and information. Yet, as Hjarvard (2011) points out, the Internet is not interested in disseminating particular religious views. Speaking up about religious teaching is not their business. The purpose is only to attract people as much as possible by displaying many "menus", including religious "menus" with various genres to earn money.

In line with the qualitative data, the survey circulated to examine the Indonesian Muslims' ways of dealing with their religious issues shows that accessing the Internet was the predominant choice which was more than $85 \%$. Reading the Holy Quran and Hadith, discussing with their families or close friends, and joining Islamic teachings through social media were three frequent activities conducted by the respondents after accessing the Internet. Interestingly, participating in religious events in the mosques and consulting the Muslim scholars representing the essential characteristics of Indonesian Muslims in their home country was only $17,6 \%$ and $5,9 \%$, respectively (table 1 ).

The findings above prove that the Internet has become the primary choice to obtain Islamic messages or information for Indonesian Muslims. The lack of integration into Islamic institutions, on the one side, and the easiness of accessing the Internet for any individual needs, on the other side, are the primary reasons encouraging the Muslim community to find different ways to fulfill their spiritual needs. As a result, the "conventional" Islamic institutions in the Hungarian context do not substantially contribute to the Indonesians' Islamic practices. In contrast, the Internet has taken over the providence of religious resources in various forms and links based on individuals' preferences.

Social media, YouTube, and Religious Authority. The last two decades have been the death of the conventional society era. How people live has changed from a natural society to a virtual organization. This happens because social networks influence the human way of life to depend highly on the networked society. This 
phenomenon challenges the classical conceptual framework of authority, including religious leaders.

The Indonesian Muslims in Hungary have experienced a new trend in their involvement in religious practices. While most are absent in any "conventional" religious communities, they actively engage in social media as a new "congregation". The community members felt that social media could be an alternative place to obtain religious information and knowledge when they experience limitations in accessing the religious communities where they live.

In-depth Interview with Ahmad Hidayat, a Ph.D. student at Szeged university, best delineates why social media become alternative spheres to fulfill his spiritual needs. According to him, on the one hand, social media kill his dullness and loneliness when just staying at home due to the coronavirus outbreak. On the other hand, the media also provide resources, including religious resources unavailable in the Islamic institutions where he lives.

Among the social media use, quantitatively, the data survey shows that YouTube was the most frequently accessed by almost $100 \%$ of the Indonesian Muslims in Hungary to deal with their religious issues and to improve their Islamic knowledge. Facebook and Instagram were other social media used by the community (figure 1). In line with this data, the worldwide statistical data shows that Facebook and YouTube are the most popular social networks, with 2,740 million and 2,291 million users, respectively, as of January 2021 (H. Tankovska 2021).

Some famous YouTube channels in Indonesia have also become favorite links for Indonesian Muslims. Ustadz Abdul Shomad (UAS), Ustadz Hanan Attaki, Ustadz Adi Hidayat (UAH), and Abdullah Gymnastiar (Aa Gym) were the most favorite YouTube channels for the respondents. Some considerations of the respondents chose the channels as the sources of Islamic information and practices as stated by Nurul Musdholifah indicated that she prefers listening to Hanan Attaki Channel because of the ability of the speaker to bring the audience into their personal experiences by illustrating some stories while speaking. In addition, Hanan Attaki shows a unique appearance that is not like other Muslim scholars. He wears clothes different from others when presenting religious teachings, like wearing a hat that is uncommon for other Muslim scholars. 
Indeed, these channels have been recognized as Islamic channels with the highest subscribers in Indonesia and earn the highest income through their content (Ekonomi.co.id 2019). But, other respondents have different preferences for accessing YouTube channels, such as Gus Baha, Ustadz Halid Basalamah, Ustadz Ali Jabir, etc. However, the number of people choosing these channels was insignificant. Even some of them do not have any preferences. They accessed various YouTube channels based on topics their needs.

Basically, YouTube and other social media, in general, do not have any interest in propagating particular religious outlooks. They are not in the business of preaching any religious messages (Hjarvard 2011). While conventional media like TV or radio have their own authority to produce and circulate religious content as one of the mediatizations of religious characteristics (Hjarvard 2011), the new media, like YouTube, open a new system of modus operandi. They just provide "new malls," allowing them to collaborate with content creators in order to create various genres to attract customers as much as possible, including religious believers. Doing this will result in money, which is the media's main purpose.

As consequences of the dominant use of social media, which is particularly in this case predominated by YouTube, are not only opening a new space for creating individual charisma (Tee 2019) but also shifting legitimate religious power from organizational to individual authority, as revealed by previous scholars on media and religions, such as Hoover (2020), Lövheim \& Lundmark (2019).

Religious organizations, mosques, or religious leaders could represent classical Islamic authority. In the Indonesian context, as the informants' home country background, the administration could be from religious organizations, such as Muhammadiyah and Nahdlatul Ulama (NU), the two biggest Islamic organizations in Indonesia. The former is associated with urban middle-class Muslims, and the latter is rusticated rural communities and traditional outlooks (Barton 2014). Meanwhile, in the Hungarian context where they are living, it could be from each mosque which has its autonomy to organize religious activities, and also could be from Hungarian Muslim organizations which are the Church of Muslims of Hungary--Magyarországi Muszlimok Egyháza, as well as the Hungarian Islamic Community--Magyar Iszlám Közösség (Hazim 2020).

However, religious content creators on YouTube recently have had more potential to influence audiences than those religious institutions. They have 
thousands, even millions, of subscribers and followers that can be associated with a "congregation" in classical religious institutions. In another world, the religious institutions' authority in communicating spiritual messages in public discourse is taken over by the content creators of social media. This is the last characteristic of the mediatization of religion conceptualized by Hjarvard $(2008,2011)$.

\section{CONCLUSION}

Understanding the mediatization of religion cannot be separated from the contexts where the study is conducted. In the context of the Indonesian Muslim diaspora in Hungary, the lack of integration into the local Islamic institutions encourages them to find alternative ways to deal with their religious issues. Some reasons hinder the minority group from being integrated into the local communities. While the language barrier is the predominant reason, conflict of time, accessibility to the mosques, and the coronavirus pandemic are other reasons limiting them from acculturating with the local Muslims. Mediatization of Islam in the Hungarian context can be seen through Indonesian Muslims' dependency on the Internet to obtain religious news and information. Most of them access social media; YouTube is their favorite, followed by Facebook and Instagram, to fulfill their spiritual needs. The dependency upon media, particularly YouTube, has the potential to shift religious authority from institutional to personal power. Finally, whether when mediatization of religion results in secularization remains debatable; the finding shows that instead of becoming more secular, the dependency upon media for Indonesian Muslims in the Hungarian context influences them to be more religious.

\section{REFERENCES}

Ali, Shaheen Sardar. 2010. "Cyberspace as Emerging Muslim Discursive Space? Online Fatawa on Women and Gender Relations and Its Impact on Muslim Family Law Norms." International Journal of Law, Policy and the Family 24(3):338-60.

Barton, Greg. 2014. “The Gülen Movement, Muhammadiyah and Nahdlatul Ulama: Progressive Islamic Thought, Religious Philanthropy and Civil Society in Turkey and Indonesia." Islam and Christian-Muslim Relations 25(3):287- 
301.

Berry, John W., and David L. Sam. 1997. “Acculturation and Adaption.” Pp. 291326 in Handbook of cross-cultural psychology, Vol. 3, Social behavior and applications.

Campbell, Heidi. 2007. "Who's Got the Power? Religious Authority and the Internet." Journal of Computer-Mediated Communication 12(3):1043-62.

Campbell, Heidi A. 2012. "Understanding the Relationship between Religion Online and Offline in a Networked Society." Journal of the American Academy of Religion 80(1):64-93.

Ekonomi.co.id, Warta. 2019. "Dakwah Lewat YouTube, 4 Ustad Kondang Ini Dapat Penghasilan Sebesar. .."

Embassy of the Republic of Indonesia in Budapest, Hungary. 2021. DATA WNI BULAN JANUARI 2021. Budapest.

H. Tankovska. 2021. "Most Popular Social Networks Worldwide as of January 2021, Ranked by Number of Active Users." Statista.

Hazim. 2020. "CHANGING FAITH: THE CONTEXTS OF RELIGIOUS CONVERSION TO ISLAM IN HUNGARY." Pp. 55-59 in Proceedings of The IIER International Conference, Moscow, Russian Federation, 10th-11th March, 2020. Moscow.

Hepp, Andreas. 2009. "Differentiation: Mediatization and Cultural Change.” Pp. 139-57 in Mediatization: Concept, changes, consequences, edited by K. Lundby. New York: NY: Peter Lang.

Hjarvard, Stig. 2008. "The Mediatization of Religion: A Theory of the Media as Agents of Religious Change." Northern Lights: Film and Media Studies Yearbook 6(1):9-26.

Hjarvard, Stig. 2011. "The Mediatisation of Religion: Theorising Religion, Media and Social Change." Culture and Religion 12(2):119-35.

Hoover, Stewart M. 2020. "Religious Authority in the Media Age." Pp. 15-36 in The Media and Religious Authority.

Hutchings, Tim. 2011. "Contemporary Religious Community and the Online Church.” Information Communication and Society 14(8):1118-35.

Lövheim, Mia. 2014. “Mediatization and Religion.” Pp. 547-70 in Mediatization of Communication. 
Lövheim, Mia, and Evelina Lundmark. 2019. "Gender, Religion and Authority in Digital Media." ESSACHESS - Journal for Communication Studies 12(2):2338.

Lynch, Gordon. 2011. "What Can We Learn from the Mediatisation of Religion Debate?" Culture and Religion 12(2):203-10.

Setianto, Yearry Panji. 2015. "Mediatization of Religion: How the Indonesian Muslim Diasporas Mediatized Islamic Practices." Journal of Media and Religion 14(4):230-44.

Tee, Caroline. 2019. "Creating Charisma Online: The Role of Digital Presence in the Formation of Religious Identity." Journal of Contemporary Religion 34(1):75-96.

Weber, Max. 1978. Economic and Society: An Outline of Interpretive Sociology. edited by \& C. W. G. Roth. Berkeley, Los Angeles, London: University of California Press. 